\title{
A Role for Platelet-Derived Growth Factor-BB in Rat Postpneumonectomy Compensatory Lung Growth
}

\author{
SHIZENG YUAN, VICKY HANNAM, ROSETTA BELCASTRO, NICHOLAS CARTEL, \\ JUDY CABACUNGAN, JINXIA WANG, YENGE DIAMBOMBA, LESLIE JOHNSTONE, \\ MARTIN POST, AND A. KEITH TANSWELL
}

The Canadian Institutes of Health Research Group in Lung Development (M.P., A.K.T.) and Lung Biology

Programme (R.B., J.C., N.C., Y.D., V.H., L.J., M.P., A.K.T., J.W., S.Y.), Hospital for Sick Children

Research Institute; and the Division of Neonatology, Department of Paediatrics (Y.D., M.P., A.K.T.), and

the Department of Physiology (M.P., A.K.T.), University of Toronto, Toronto, Ontario M5S 1A8, Canada

\begin{abstract}
Unilateral pneumonectomy leads to compensatory growth in the residual lung, the mediators of which are largely unknown. We hypothesized, based on its other known roles in lung cell growth, that platelet-derived growth factor (PDGF)-BB would be an essential mediator of postpneumonectomy compensatory lung growth. Left-sided pneumonectomies were performed on 21-dold rats, for comparison with sham-operated or unoperated control animals. Body weights were not different between groups. Right lung weights and DNA content were significantly increased $(p<0.05)$, compared with controls, by $10 \mathrm{~d}$ after pneumonectomy. The rate of DNA synthesis was maximal on $d$ 5 postpneumonectomy. Total right lung PDGF-B mRNA and PDGF-BB protein increased after pneumonectomy, but were apparently tightly regulated, relative to total right lung $\beta$-actin mRNA and protein content, respectively. However, PDGF-BB expression after pneumonectomy was apparently not purely con-
\end{abstract}

ABSTRACT

stitutive, in that daily i.p. injections of a truncated soluble PDGF $\beta$-receptor both reduced activation of the native PDGF $\beta$-receptor, and attenuated increased lung DNA synthesis on $\mathrm{d} 3$ after pneumonectomy. These findings are consistent with a critical role for PDGF-BB in postpneumonectomy lung growth. (Pediatr Res 52: 25-33, 2002)

Abbreviations
NGF, nerve growth factor
NGF-R/Fc, nerve growth factor receptor/Fc chimera soluble
truncated receptor

PDGF, platelet-derived growth factor

PDGF-R $\boldsymbol{\beta}$, platelet-derived growth factor $\beta$-receptor

PDGF-R $\boldsymbol{\beta} / \mathbf{F c}$, platelet-derived growth factor $\beta$-receptor/Fc chimera soluble truncated receptor

PMSF, phenylmethylsulfonyl fluoride
Children and adolescents subjected to a unilateral pneumonectomy develop a varying degree of compensatory growth in the contralateral lung (1). Extensive animal studies have enhanced our understanding of this process (2-7). The degree of compensatory growth achieved is reduced with age, but, if lung tissue is removed sufficiently early in life, there is an almost complete restitution of air space, capillary and tissue volumes, and alveolar and capillary surface areas to normal $(8,9)$. Physiologic, pathophysiological, and morphologic studies suggest that, at least in small animal species, this compensatory growth occurs within the first 2 wk after surgery $(5,6,10)$.

Received June 26, 2001; accepted February 12, 2002.

Correspondence: Keith Tanswell, Division of Neonatology, Hospital for Sick Children, 555 University Avenue, Toronto, Ontario M5G 1X8, Canada; e-mail: keitht@sickkids.on.ca

Supported by a group grant from the Canadian Institutes of Health Research, and an equipment grant from the Ontario Thoracic Society.

K.T. holds the Women's Auxiliary Chair in Neonatal Medicine, Hospital for Sick Children, Toronto.
Cellular hyperplasia is evident during compensatory lung growth $(10,11)$, with increased mitotic indices of parenchymal cells, total DNA, and DNA synthesis (as measured by incorporation of $\left[{ }^{3} \mathrm{H}\right]$ thymidine) having been observed in rats $(10-$ 13), mice (14), and rabbits (6).

Successful postpneumonectomy lung growth is likely to require the coordinated expression of various growth factors and their receptors, directed at the different cell types within the lung (15), acting through autocrine, endocrine, juxtacrine, or paracrine pathways. Despite an extensive literature relating to experimental pneumonectomy, the mediators of compensatory growth in the residual lung tissue have not been elucidated. It has been shown that the immediate-early genes $c$-fos and $j u n-B$ are up-regulated very rapidly (30 min) after pneumonectomy (16). However, the downstream events that follow this early response, and mediate the proliferative response, are not clear. It has been suggested that tumor necrosis factor may be one of the hormonal factors implicated in postpneumonec- 
tomy lung growth (17). IGF-I does not appear to be an endocrine growth factor after pneumonectomy in rabbits (18). Altered expression of IGF-I has been both reported to play (19), and not play (20), a role in postpneumonectomy lung growth in rats. An increase in IGF-I has been reported after pneumonectomy in lambs (21). Serum concentrations of hepatocyte growth factor increase after pneumonectomy in adult humans (22).

Other growth factors involved in compensatory lung growth after pneumonectomy, including the PDGF-BB homodimer, have not yet, to our knowledge, been studied. PDGF-BB is well recognized to play a critical role in early lung development $(23,24)$, and to be up-regulated during lung injury $(25)$. Based on our previous observations that PDGF-BB mediates stretch-induced fetal lung cell proliferation in vitro (26), and the probable role of tissue expansion in initiating compensatory lung growth (7), we hypothesized that PDGF-BB would also be a critical mediator in vivo for postpneumonectomy compensatory lung growth.

\section{METHODS}

Materials. Radioisotopes were from ICN Radiochemicals (Irvine, CA, U.S.A.), nylon membranes and RNAguard were from Amersham Canada (Oakville, Ontario, Canada), and restriction enzymes and dextran sulfate were from Pharmacia (Baie D'Urfé, Québec, Canada). BSA type V, Ficoll 400, polyvinylpyrrolidone, guanidinium thiocyanate, cesium chloride, poly(L-lysine), PMSF, and salmon sperm DNA were from Sigma Chemical (St. Louis, MO, U.S.A.). A genomic DNA isolation reagent (DNAzol) was from Molecular Research Center (Cincinnati, OH, U.S.A.). Protein assay kits were from Bio-Rad (Hercules, CA, U.S.A.). ECL Western blotting detection reagents were from Amersham Life Science (Little Chalfont, Buckinghamshire, U.K.). Fluorescent dye (Hoescht 33258) was from Polysciences (Warrington, PA, U.S.A.). Enflurane (Ethrane), the inhalation anesthetic, was from Zeneca Pharma (Mississauga, Ontario, Canada). Ketamine, atropine, and pentobarbital (Euthanyl) were from MTC Pharmaceuticals (Cambridge, Ontario, Canada), and acepromazine (Atravet) from Ayerst Laboratories (Montreal, Québec, Canada). Buprenorphine, for postoperation pain relief, was from Reckitt \& Colman Products (Hull, England). Organic solvents were of HPLC grade. Porcine trypsin (1:250), proteinase K, and ribonuclease (RNase)-A were from Invitrogen Canada (Burlington, Ontario, Canada). Rabbit anti-human PDGF-BB polyclonal IgG was from Genzyme (Cambridge, MA, U.S.A.). Rabbit anti-human PDGF-R $\beta$ polyclonal IgG, mouse monoclonal $\mathrm{IgG}_{2 \mathrm{~b}}$ antibody to phosphotyrosine (PY99), and goat antimouse monoclonal IgG conjugated with peroxidase were from Santa Cruz Biotechnology (Santa Cruz, CA, U.S.A.). Goat anti-rabbit IgG conjugated with peroxidase was from Roche Molecular Biochemicals (Indianapolis, IN, U.S.A.). Human recombinant PDGF-BB was from Upstate Biotechnology (Lake Placid, NY, U.S.A.). A kit for avidin-biotin peroxidase complex immunocytochemical staining was purchased from Vector Laboratories (Burlingame, CA, U.S.A.). $\alpha$-Aminopropyl-triethoxysilane and the Fc fragment of goat anti-human
IgG were from Pierce Chemical (Rockford, IL, U.S.A.). Human PDGF-R $\beta / \mathrm{Fc}$ and NGF-R $\beta / \mathrm{Fc}$ chimeras, soluble truncated receptors for PDGF-BB and NGF, respectively, were purchased from R \& D Systems (Minneapolis, MN, U.S.A.). Goat $\operatorname{IgG}(\mathrm{Fc})$ was from Serotec (Raleigh, NC, U.S.A.).

Pneumonectomy. All procedures involving animals were conducted according to criteria established by the Canadian Council for Animal Care, and prior approval was obtained from the Animal Care Review Committee at the Hospital for Sick Children Research Institute. Left unilateral pneumonectomies were performed on Wistar rat pups at $21 \mathrm{~d}$ of age. The pups were premedicated with a mixture of ketamine (14.7 $\mathrm{mg} / \mathrm{kg})$, atropine $(22.5 \mu \mathrm{g} / \mathrm{kg})$, and acepromazine $(0.3 \mathrm{mg} / \mathrm{kg})$, then intubated under direct vision using a size-fit cannula. They were connected to a BP-200 volume-cycled infant pressure ventilator (Bourns Medical Systems, Riverside, CA, U.S.A.), delivering a tidal volume of $10 \mathrm{~mL} / \mathrm{kg}$ at a rate of $75-80$ breaths/min. The left side of the chest was shaved and sterilized with $75 \%$ (vol $/ \mathrm{vol})$ ethanol. An incision was made in the fifth left intercostal space and the pleural cavity was opened under $0.75 \%$ (vol $/ \mathrm{vol})$ enflurane general anesthesia. The ECG was monitored during operation with a 78534A monitor from Hewlett Packard (Palo Alto, CA, U.S.A.). Blood oxygen saturation was continuously monitored with an N-100 pulse oximeter (Nellcor Inc., Hayward, CA, U.S.A.). The exposed left lung was exteriorized using blunt forceps. The hilum was then clamped and ligated and the lung was removed. The thoracic cavity was then closed with two layers of sutures. After removal of the lung, intermitted positive-pressure ventilation with $100 \% \mathrm{O}_{2}$ was briefly maintained to ensure adequate inflation of the right lung. Intramuscular buprenorphine $(0.5$ $\mathrm{mg} / \mathrm{kg}$ ) was used to provide postoperative analgesia. Shamoperated control pups were treated similarly to the pneumonectomized animals, except that the lung was not removed after puncturing the plural cavity. An additional control group received premedication only. Lung and body weights were recorded at 3,5,7, and $10 \mathrm{~d}$ after pneumonectomy.

Lung DNA content and $\left.\Gamma^{3} H\right]$ thymidine incorporation into DNA. Under anesthesia, the chest was opened and lungs were removed and immediately frozen in liquid nitrogen. Weighed aliquots of lung tissues were homogenized with a Polytron (PT-10 ${ }^{-35}$, Kinematica GmbH, Littau, Switzerland) in lysis buffer [100 mM NaCl, $10 \mathrm{mM}$ Tris, $25 \mathrm{mM}$ EDTA, $0.5 \%$ ( vol $/ \mathrm{vol}$ ) SDS; $\mathrm{pH} 8.0]$ and incubated overnight at $50^{\circ} \mathrm{C}$ in the presence of proteinase $\mathrm{K}(0.1 \mathrm{mg} / \mathrm{mL})$. For quantitative measurement, DNA was then extracted with an equal volume of phenol/chloroform/isoamyl alcohol (25:24:1, vol/vol/vol) and precipitated by adding a half volume of $7.5 \mathrm{M}$ ammonium acetate and two volumes of $100 \%$ (vol $/ \mathrm{vol}$ ) ethanol (27). DNA concentrations were measured, after the samples were diluted to the linear range of a standard curve $(0.01-1 \mu \mathrm{g} / \mathrm{mL})$, using a fluorescent dye technique (28). To assess DNA synthesis, rat pups were injected with intraperitoneal (i.p.) $\left[{ }^{3} \mathrm{H}\right]$ thymidine $(1$ $\mathrm{mCi} / \mathrm{kg}$ ) $2 \mathrm{~h}$ before removal of lung tissue. For measurement of $\left[{ }^{3} \mathrm{H}\right]$ thymidine incorporation into DNA, a single-step procedure for genomic DNA isolation, using the DNAzol reagent, was used to extract DNA (29), and DNA synthesis was determined by measuring the $\beta$-emissions, as dpm, of equal 
amounts of $\left[{ }^{3} \mathrm{H}\right]$ thymidine-labeled DNA in a liquid scintillation spectrometer (1219, LKB-Wallac Rackbeta, Turku, Finland).

Isolation of lung $\boldsymbol{R} \boldsymbol{N} \boldsymbol{A}$. Briefly, the thoracic contents were removed en bloc and the lungs dissected away from vessels and large airways to be flash frozen in liquid nitrogen. Weighed lung tissue samples were homogenized in a denaturing solution containing $4 \mathrm{M}$ guanidium thiocyanate, and total (nuclear and cytoplasmic) RNA was isolated following the method of Chomczynski and Sacchi (30). After extraction with phenol/ chloroform $(1: 1, \mathrm{vol} / \mathrm{vol})$ the RNA was ethanol precipitated and collected by centrifugation. This RNA was lyophilized and dissolved in $0.02 \%$ ( $\mathrm{vol} / \mathrm{vol}$ ) diethyl pyrocarbonate-treated water. All RNA samples were stored at $-70^{\circ} \mathrm{C}$ in the presence of a RNase inhibitor, RNAguard ( $0.15 \mathrm{U} / \mu \mathrm{g}$ RNA). Integrity of RNA was assessed visually after fractionation on $1.2 \%(\mathrm{wt} /$ vol) agarose-formaldehyde gels from the appearance of the 28 and $18 \mathrm{~S}$ ribosomal RNA bands stained with ethidium bromide.

Generation of PCR probes. Total RNA was isolated and reverse transcriptase PCR was performed as previously described (31). The amplified PCR products were then gelpurified and ligated into PCR II (Invitrogen, San Diego, CA, U.S.A.) with T4 DNA ligase. After transformation of competent Escherichia coli, several colonies were picked for sequence analysis using the dideoxy chain termination method (Pharmacia) according to the manufacturer's instructions. Sequence analysis showed a $>95 \%$ homology to the published sequence. The primers for PDGF-B, 5'-AGTCGGCATGAATCGCTGCTGGG-3' and 5'-TTTCTCACCTGGACCGGCCGCAT-3', were based on the murine genomic sequence (32) and when amplified gave a fragment of $476 \mathrm{bp}$. The primers for PDGF-R $\beta$, 5'-CGACGATTCCATGCCGAGTGACA-3' and 5'-AGTGGACAGAACCAACTCGCC-3', were based on a rat cDNA sequence (Genbank number: RNDPDGRRBE), giving a $654 \mathrm{bp}$ fragment. The primers for rat $\beta$-actin, 5'-TTGTAACCAACTGGGACGATATGG-3' and 5'GATCTTGATCTTCATGGTGCTAGG-3', were based on the rat genomic sequence (33) and when amplified gave a fragment of $764 \mathrm{bp}$. The reverse transcriptase PCR-generated cDNAs were excised from PCR II plasmids by restriction digestion, labeled with $\left[\alpha_{-}{ }^{32} \mathrm{P}\right] \mathrm{dCTP}$ by random hexamer priming and used as hybridization probes.

Northern blot analysis. All Northern blot analyses were performed as previously described (34), using $20 \mu \mathrm{g}$ of RNA. The total RNA samples were denatured in a loading buffer containing $3.2 \mathrm{M}$ formaldehyde for $5 \mathrm{~min}$ at $65^{\circ} \mathrm{C}$ and electrophoresed in $1.2 \%(\mathrm{wt} / \mathrm{vol})$ agarose gels containing $0.66 \mathrm{M}$ formaldehyde. The RNAs were transferred to Hybond- ${ }^{+}$ nylon membrane (Amersham Health, Arlington Heights, IL, U.S.A.) using the capillary transfer technique. After transfer, the blots were air dried and fixed in a UV cross-linker (Stratagene, La Jolla, CA, U.S.A.). All probes were labeled with deoxycytidine $5^{\prime}-\left[\alpha-{ }^{32} \mathrm{P}\right]$ triphosphate by a random primed labeling system (Amersham Health), with specific activities of $0.5-2.9 \times 10^{9}$ counts $\times \min ^{-1} \times \mu \mathrm{g} \mathrm{DNA}^{-1}$. Prehybridization $(5 \mathrm{~h})$ and hybridizations $(>16 \mathrm{~h})$ at $42^{\circ} \mathrm{C}$ were performed in $50 \%$ (vol/vol) formamide; $750 \mathrm{mM} \mathrm{NaCl} ; 75 \mathrm{mM}$ sodium citrate; $\times 5$ Denhardt's solution $[=0.1 \%(\mathrm{wt} / \mathrm{vol})$ each of BSA,
Ficoll, and polyvinylpyrrolidone]; $10 \%$ (wt/vol) dextran sulfate; and $100 \mu \mathrm{g} / \mathrm{mL}$ denatured salmon sperm DNA. Washes varied with the probe used. PDGF-B blots were twice washed in $2 \times \mathrm{SSC}(=300 \mathrm{mM} \mathrm{NaCl}, 30 \mathrm{mM}$ sodium citrate, $\mathrm{pH} 7.0)$ and $0.1 \%(\mathrm{wt} / \mathrm{vol}) \mathrm{SDS}$ for $10 \mathrm{~min}$ at room temperature, followed by a more stringent wash in $1 \times \mathrm{SSC}$ and $0.2 \%$ $\left(\mathrm{wt} / \mathrm{vol}\right.$ ) for $2-5 \mathrm{~min}$ at $42^{\circ} \mathrm{C}$. Blots hybridized with the PDGF-R $\beta$ were washed in $2 \times \mathrm{SSC}$ and $0.1 \%(\mathrm{wt} / \mathrm{vol})$ for 10 $\mathrm{min}$ at room temperature followed by a second, more stringent wash in $1 \times \mathrm{SSC}$ and $0.2 \%(\mathrm{wt} / \mathrm{vol}) \mathrm{SDS}$ for $2 \mathrm{~min}$ at $42^{\circ} \mathrm{C}$. After stripping, blots were hybridized with the $\beta$-actin probe (33), then washed in $2 \times \mathrm{SSC}$ and $0.1 \%(\mathrm{wt} / \mathrm{vol})$ for $10 \mathrm{~min}$ at room temperature followed by a second, more stringent wash in $1 \times \mathrm{SSC}$ and $0.2 \%(\mathrm{wt} / \mathrm{vol})$ for $2 \mathrm{~min}$ at $42^{\circ} \mathrm{C}$. The blots were exposed for $24-48 \mathrm{~h}$ at $-70^{\circ} \mathrm{C}$ to Kodak XAR-5 film (Eastman Kodak, Rochester, NY, U.S.A.) using DuPont Cronex intensifying screens (DuPont, Wilmington, DE, U.S.A.). The films were quantified by an Ultroscan XL laser densitometer (LKB, Uppsala, Sweden), and results expressed as arbitrary units (AU) per sample . For calculations of mRNA content in whole lung, PDGF-B and PDGF-R $\beta$ mRNA values were corrected for sample dilution. To compensate for variations in RNA transfer, all results were normalized against the d-0 control values for individual gels.

Autoradiography and immunohistochemistry. Animals received $\left[{ }^{3} \mathrm{H}\right]$ thymidine $(1 \mathrm{mCi} / \mathrm{kg}$, i.p.) $2 \mathrm{~h}$ before sacrifice. They were deeply anesthetized with pentobarbital $(200 \mathrm{mg} / \mathrm{kg})$. A tracheal catheter was inserted and sutured in place to facilitate lung inflation. The anterior part of the chest wall was reflected upward. While the heart was beating, a 23-gauge needle was inserted through the right ventricle, and an incision made in the left atrial appendage to allow drainage. The pulmonary circulation was then flushed with PBS containing 1 $\mathrm{U} / \mathrm{mL}$ heparin, during intermittent lung inflation, until the lungs became white. The lungs were subsequently fixed by perfusion with freshly prepared $4 \%(\mathrm{wt} / \mathrm{vol})$ paraformaldehyde under a constant airway pressure of $12 \mathrm{~cm} \mathrm{H}_{2} \mathrm{O}$. The middle lobe of the right lung was embedded in paraffin and cut in 5 - $\mu \mathrm{m}$ sections. Sections were mounted on $\alpha$-aminopropyltriethoxysilane-coated slides.

Slides were coated with Kodak NBT-3 emulsion and developed after 4 wk at $4{ }^{\circ} \mathrm{C}$ for autoradiography. The slides were lightly counterstained with Carazzi hematoxylin. Cells undergoing active DNA synthesis were identified by the presence of silver granules over cell nuclei, with positive labeling being defined according to the criteria of Chwalinski et al. (35). A total of five random microscope fields $(\times 400$ magnification) were counted from each of two animals at each time point. Because only two animals were used for each data point, a second set of animals was similarly studied to show reproducibility of results.

Immunohistochemistry studies were conducted using an avidin-biotin-peroxidase complex method (36). Dilutions of the primary antisera were 1:200 for PDGF-BB (rabbit anti-human $\operatorname{IgG}$ ) and 1:1200 for PDGF-R $\beta$ (rabbit anti-human IgG). Dilutions for secondary antisera, goat anti-rabbit IgG conjugated with peroxidase, were 1:200 and 1:600, respectively. Slides were lightly counter-stained with Carazzi hematoxylin, dehy- 
drated, cleared in xylene, and mounted. Three animals were studied for each time point. Slides from different groups were processed in parallel. Illustrations represent findings evident in all three animals.

Western blot analysis. Lung tissues were homogenized with five volumes of lysis buffer containing $1 \%$ (vol/vol) NP40, $0.5 \%(\mathrm{wt} / \mathrm{vol})$ sodium deoxycholate, $0.1 \%(\mathrm{wt} / \mathrm{vol}) \mathrm{SDS}$, and $100 \mu \mathrm{g} / \mathrm{mL}$ PMSF in PBS. The homogenate was left on ice for $30 \mathrm{~min}$ before centrifugation at $10,000 \times \mathrm{g}$. Protein content was estimated according to the method of Bradford (37). Aliquots of $100 \mu \mathrm{g}$ of homogenate protein were diluted with sample buffer containing $125 \mathrm{mM}$ Tris, $20 \%$ (wt/vol) glycerol, and $4 \%(\mathrm{wt} / \mathrm{vol})$ SDS and separated on $15 \%(\mathrm{wt} / \mathrm{vol})$ polyacrylamide gels with $0.1 \%$ (vol/ $/ \mathrm{vol}$ ) SDS. Proteins were subsequently transferred to a nitrocellulose membrane. Nonspecific binding was blocked by incubation with $5 \%$ ( $\mathrm{vol} / \mathrm{vol})$ normal goat serum and $1 \%$ (wt/vol) BSA in PBS for $1 \mathrm{~h}$ at $20^{\circ} \mathrm{C}$ with shaking, followed by overnight incubation with a 1:500 ( $\mathrm{vol} / \mathrm{vol}$ ) dilution of primary antibody of rabbit antihuman PDGF-BB, or a 1:250 (vol/vol) dilution of primary antibody of rabbit anti-human PDGF-R $\beta$. Membrane was subsequently incubated with $1: 30,000$ (vol/vol) dilution, for PDGF-BB, or a 1:20,000 (vol/vol) dilution, for PDGF-R $\beta$, of goat anti-rabbit $\operatorname{IgG}$ conjugated with peroxidase for $1 \mathrm{~h}$ at $20^{\circ} \mathrm{C}$. For calculations of protein content in whole lung, PDGF-BB values were corrected for sample dilution. To compensate for variations in transfer, all results were normalized against the d-0 control values for individual gels. For the study of receptor phosphorylation, samples were obtained from paired litter mates, derived from four separate litters. A mouse monoclonal $\mathrm{IgG}$ for phosphotyrosine (PY99) was diluted to $1: 100,000$, with the secondary antisera of goat anti-mouse IgG diluted to 1:2000. Between each incubation step, the membrane

Table 1. Effect of pneumonectomy on body weight

\begin{tabular}{cccc}
\hline $\begin{array}{c}\text { Days } \\
\text { postpneumonectomy }\end{array}$ & $\begin{array}{c}\text { Control } \\
(\mathrm{g})\end{array}$ & $\begin{array}{c}\text { Sham-operated } \\
(\mathrm{g})\end{array}$ & $\begin{array}{c}\text { Pneumonectomy } \\
(\mathrm{g})\end{array}$ \\
\hline 0 & $47.4 \pm 1.2$ & - & - \\
3 & $54.6 \pm 3.3$ & $57.7 \pm 4.1$ & $53.3 \pm 1.8$ \\
5 & $64.5 \pm 3.0$ & $65.9 \pm 3.7$ & $64.0 \pm 4.2$ \\
7 & $74.7 \pm 2.5$ & $74.4 \pm 3.0$ & $69.8 \pm 2.3$ \\
10 & $97.6 \pm 7.1$ & $91.2 \pm 3.1$ & $94.3 \pm 3.5$ \\
\hline
\end{tabular}

Body weights of unoperated animals (control) were compared with those of animals subjected to sham-operation or pneumonectomy on $\mathrm{d} 21$ of life (d 0$)$. Values are means \pm SEM from four animals in each group. No differences were seen among groups ( $p>0.05$ by ANOVA).
Table 3. Effect of left pneumonectomy on right lung DNA content

\begin{tabular}{cccc}
\hline $\begin{array}{c}\text { Days } \\
\text { postpneumonectomy }\end{array}$ & $\begin{array}{c}\text { Control } \\
(\mathrm{mg})\end{array}$ & $\begin{array}{c}\text { Sham-operated } \\
(\mathrm{mg})\end{array}$ & $\begin{array}{c}\text { Pneumonectomy } \\
(\mathrm{mg})\end{array}$ \\
\hline 0 & $1.67 \pm 0.25$ & - & - \\
3 & $1.81 \pm 0.07$ & $2.24 \pm 0.20$ & $3.00 \pm 0.06$ \\
5 & $1.87 \pm 0.16$ & $2.07 \pm 0.39$ & $3.58 \pm 0.57^{*}$ \\
7 & $1.90 \pm 0.52$ & $2.29 \pm 0.23$ & $4.73 \pm 0.67^{*}$ \\
10 & $2.02 \pm 0.38$ & $2.79 \pm 0.41$ & $6.55 \pm 0.81^{*}$ \\
\hline
\end{tabular}

DNA content in right lungs of unoperated animals (control) was compared with that of animals subjected to sham-operation or pneumonectomy on d 21 of life $(\mathrm{d} 0)$. Values are means \pm SEM from four animals in each group. Lung DNA content was significantly increased ( $* p<0.05$ by ANOVA) in pneumonectomized rats, compared with those of control or sham-operated rats, on d 5, 7, and 10 after pneumonectomy.

was thoroughly washed with cold PBS $(10 \min \times 3)$. The peroxidase reaction was carried out using ECL Western blotting detection reagents.

Inactivation of PDGF-BB with PDGF-R $/ F$ c. Bioactivity of the PDGF-R $\beta / F c$ chimera was initially confirmed in vitro by attenuation of PDGF-BB-mediated enhancement of DNA synthesis by fetal rat lung distal epithelial lung cells, but no independent effect on DNA synthesis (data not shown). The PDGF-R $\beta / F \mathrm{c}$ was injected i.p. $(\approx 0.6 \mathrm{mg} / \mathrm{kg})$ immediately after pneumonectomy, then daily for $48 \mathrm{~h}$. This concentration was based on preliminary experiments to define maximal inhibitory effects (data not shown). The PDGF-R $\beta / \mathrm{Fc}$ chimera was dissolved in $0.2 \%$ (wt $/ \mathrm{vol}) \mathrm{BSA}$ in PBS. Control experiments, to exclude nonspecific effects, were conducted using $\approx 0.6 \mathrm{mg} / \mathrm{kg}$ of either an NGF-R/Fc chimera or the Fc fragment of goat IgG.

Data presentation. Unless otherwise stated, all numerical values are shown as mean \pm SEM of four litters for each time point. Statistical significance $(p<0.05)$ was determined by an ANOVA followed by assessment of differences using Duncan's multiple range test (38) or a paired $t$ test (39). SE bars are not evident for all data points shown in the figures because they fall within the plot point.

\section{RESULTS}

Pneumonectomy, or sham operation, had no adverse effect on gains in body weight, relative to control rats (Table 1). Sham operation had no effect on lung weights (Table 2). Significantly increased $(p<0.05)$ right lung weights were observed in the pneumonectomized group as early as $\mathrm{d} 3$ postpneumonectomy (Table 2). Right lung DNA content progressively increased to d 10 after pneumonectomy $(\approx 3$-fold

Table 2. Effect of left pneumonectomy on right and combined lung weights

\begin{tabular}{|c|c|c|c|c|c|}
\hline $\begin{array}{c}\text { Days } \\
\text { postpneumonectomy }\end{array}$ & \multicolumn{2}{|c|}{ Control (g) } & \multicolumn{2}{|c|}{ Sham-operated (g) } & $\begin{array}{c}\text { Pneumonectomy (g) } \\
\text { Right (total) }\end{array}$ \\
\hline 0 & $0.28 \pm 0.01$ & $0.43 \pm 0.01$ & - & - & - \\
\hline 5 & $0.33 \pm 0.02$ & $0.57 \pm 0.04$ & $0.33 \pm 0.02$ & $0.55 \pm 0.04$ & $0.47 \pm 0.02 *$ \\
\hline 7 & $0.37 \pm 0.01$ & $0.61 \pm 0.02$ & $0.37 \pm 0.02$ & $0.61 \pm 0.04$ & $0.51 \pm 0.03 *$ \\
\hline 10 & $0.48 \pm 0.03$ & $0.75 \pm 0.04$ & $0.48 \pm 0.05$ & $0.74 \pm 0.06$ & $0.69 \pm 0.03^{*}$ \\
\hline
\end{tabular}

Right and combined lung weights of unoperated animals (control) were compared with those of animals subjected to sham-operation or pneumonectomy on d 21 of life $(\mathrm{d} 0)$. Values are means \pm SEM from four animals in each group. Right lung weights were significantly increased (* $p<0.05$ by ANOVA) after left pneumonectomy, compared with those of control or sham-operated rats at all time points studied. 


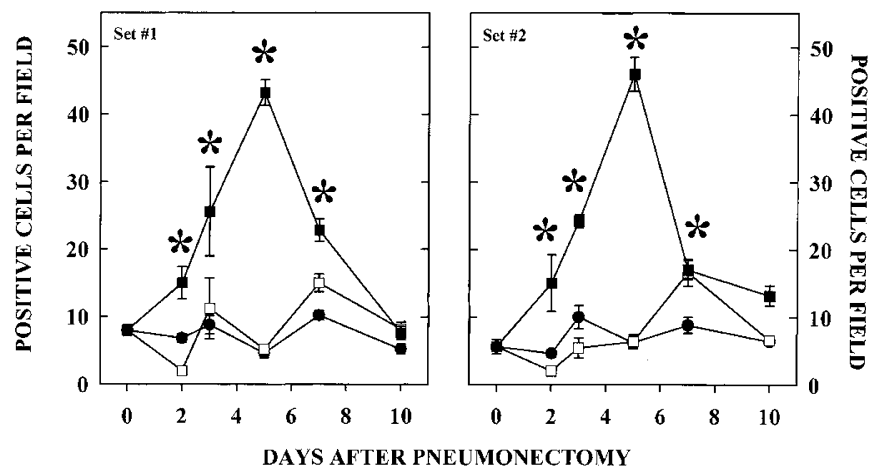

Figure 1. DNA synthesis after pneumonectomy of the left lung was evaluated by $\left[{ }^{3} \mathrm{H}\right]$ thymidine autoradiography of the right lung. Values are means \pm SEM of five fields from each of two animals in each group. A significant increase ${ }^{*} p<0.05$ by ANOVA) in the number of cells undergoing DNA synthesis was observed at 2, 3, 5, and $7 \mathrm{~d}$ after pneumonectomy (filled squares), compared with shamoperated (open squares) or control (filled circles) rats. Peak incorporation of $\left[{ }^{3} \mathrm{H}\right]$ thymidine into lung cell nuclei was at d 5 after pneumonectomy.

control values), with statistical significance being evident ( $p<$ 0.05 ) from d 5 (Table 3 ). As would be expected in animals $\geq 21$ $\mathrm{d}$ of age, right lung DNA content in control or sham-operated animals was not statistically different with time throughout the

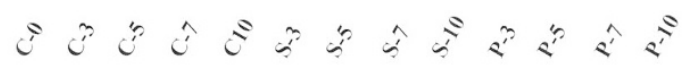

PDGF-B $-\infty-\infty-\infty-\infty-\infty$
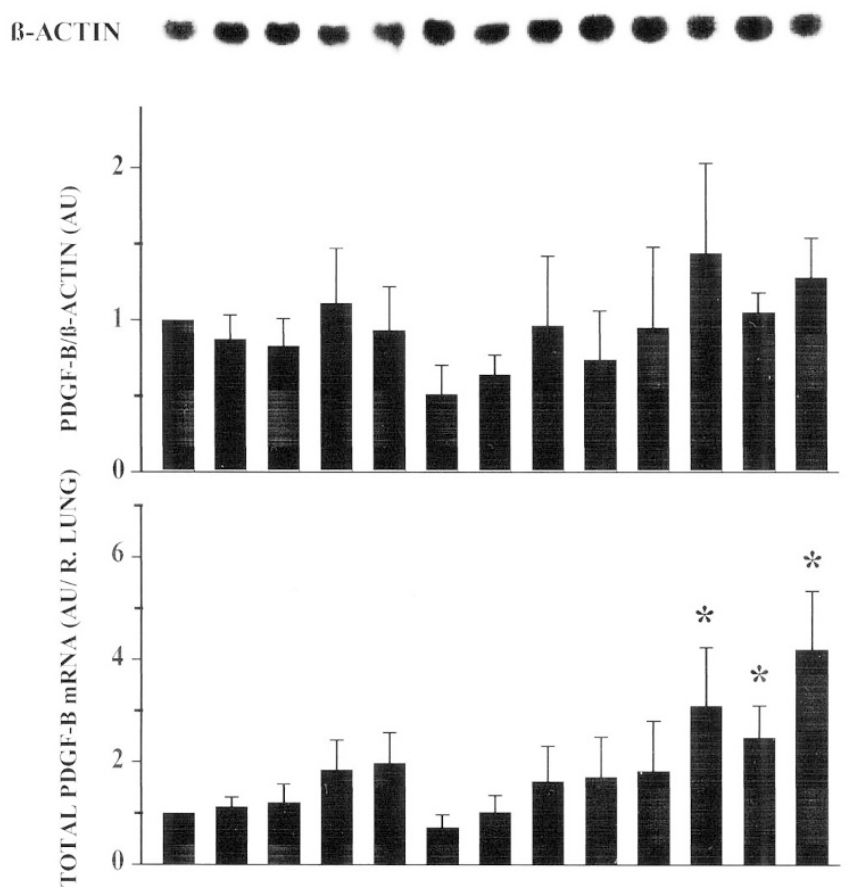

Figure 2. Northern blot analyses of PDGF-B and $\beta$-actin mRNA expression (20 $\mu \mathrm{g}$ RNA/lane) revealed single transcripts, as illustrated in the upper panel. $C$, control; $S$, sham operated; $P$, pneumonectomized. Total PDGF-B mRNA content in the right lung (arbitrary units), after correction for sample dilution, was significantly increased ( $* p<0.05$ by ANOVA) on $\mathrm{d} 5,7$, and 10 after left pneumonectomy, as compared with d 0 (lower panel). However, no significant increase was evident when PDGF-B mRNA content was expressed as a ratio against $\beta$-actin mRNA content (middle panel). Values are means \pm SEM for four animals in each group. period of observation (Table 3). Labeling of lung cell nuclei with $\left[{ }^{3} \mathrm{H}\right]$ thymidine, indicative of active DNA synthesis, was significantly $(p<0.05)$ increased from $\mathrm{d} 2$ to $\mathrm{d} 7$ after pneumonectomy, with maximum labeling ( $\approx 5$-fold increase) occurring on d 5 (Fig. 1). No significant increase in labeling of DNA with time was evident in the lungs of either control or sham-operated animals.

As shown in Figure 2, total PDGF-B mRNA content in the right lung, expressed as AU, significantly increased $(p<0.05)$ from d 5 to d 10 after pneumonectomy (lower panel). However, these changes in mRNA expression were no longer evident when PDGF-B mRNA content was normalized for $\beta$-actin mRNA content (upper and middle panels), or expressed against ribosomal RNA (data not shown). An essentially similar pattern was observed with replicate analyses of the PDGF-R $\beta$ mRNA (data not shown). These findings are consistent with a tightly regulated increase in mRNA content in proportion to the increase in lung mass.

Consistent with the mRNA findings, total immunoreactive PDGF-BB content in the right lung increased $(p<0.05)$ with lung growth on $\mathrm{d} 7$ and 10 after pneumonectomy (Fig. 3A). However, this also appeared to be tightly regulated, maintaining a constant PDGF-BB content when expressed as U/mg protein (Fig. 3B). In keeping with the Western analysis, PDGF-BB immunohistochemistry did not reveal any obvious gross difference in total immunoreactivity or distribution of immunoreactivity among control, sham-operated, and pneumonectomized groups. Figure 4 is an illustration of immunostaining from $\mathrm{d} 7$ animals. A similar lack of any differences between groups was also evident for PDGF-R $\beta$ immunoreactivity (Fig. $5)$. Similar findings were observed at all time points studied ( $d$ $3,5,7$, and 10).

$\begin{array}{lllllllllllll}\text { C-1 } & \text { C-3 } & \text { C-5 } & \text { C-7 } & \text { C-10 } & \text { S-3 } & \text { S-5 } & \text { S-7 } & \text { S-10 } & \text { P-3 } & \text { P-5 } & \text { P-7 } & \text { P-10 }\end{array}$
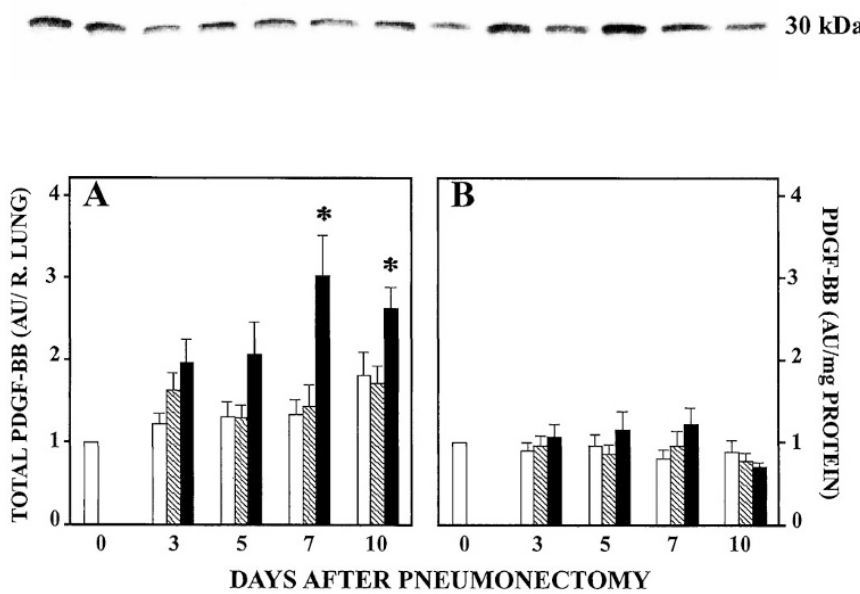

Figure 3. Western blot analysis for PDGF-BB protein content in right lungs (100 $\mu \mathrm{g}$ protein/lane) revealed a single band, as illustrated in the upper panel. $C$, control; $S$, sham operated; $P$, pneumonectomized. $(A)$ When corrected for dilution, total immunoreactive PDGF-BB significantly ( $* p<0.05$ by ANOVA) increased in the right lung on $\mathrm{d} 7$ and 10 after left pneumonectomy (solid bar), as compared with control (open bar) and sham-operated (hatched bar) rats. $(B)$ In keeping with the mRNA findings, this increase in immunoreactive PDGF-BB was no longer evident once values were normalized for lung protein content. Values are means \pm SEM for three animals in each group. 
The lack of any obvious change in mRNA or protein for PDGF-BB or PDGF-R $\beta$, after normalization, was consistent with a simple correction to prepneumonectomy constitutive values, but did not rule out a role for PDGF-BB and its receptor in compensatory growth. Intervention with a soluble receptor was used to determine whether PDGF-BB did have such a role. Binding of the soluble receptor to endogenous PDGF-BB prevents binding of this ligand to its natural receptor, and receptor activation. This should inhibit any PDGF-BBmediated compensatory lung growth. Intraperitoneal injection of the PDGF-R $\beta / \mathrm{Fc}$ chimera resulted in a reduction of pulmonary PDGF-BB immunoreactivity (Fig. 6), confirming that i.p. injection allowed an adequate delivery of the PDGF-R $\beta / \mathrm{Fc}$ chimera to the lung. Slides were also stained for endothelin-1 (an arbitrary choice for a control ligand) to exclude a nonspecific blocking effect, and no differences were observed between groups (data not shown). Four animals each received either i.p. PDGF-R $\beta / F c$ chimera or vehicle for 3 consecutive days after pneumonectomy. Western blot analysis (Fig. 7A) was used to confirm that binding of the truncated PDGF-R $\beta / \mathrm{Fc}$ chimera soluble receptor to PDGF-BB inhibited activation of the native pulmonary PDGF-R $\beta$. A significant $(p<0.05)$ reduction in immunoreactive PDGF-R $\beta$ tyrosine phosphorylation was evident in the lungs of animals that had received the PDGF-R $\beta / \mathrm{Fc}$ chimera (Fig. 7B). No significant reduction $(p>0.05)$ was observed in control animals injected with NGF-R/Fc chimera
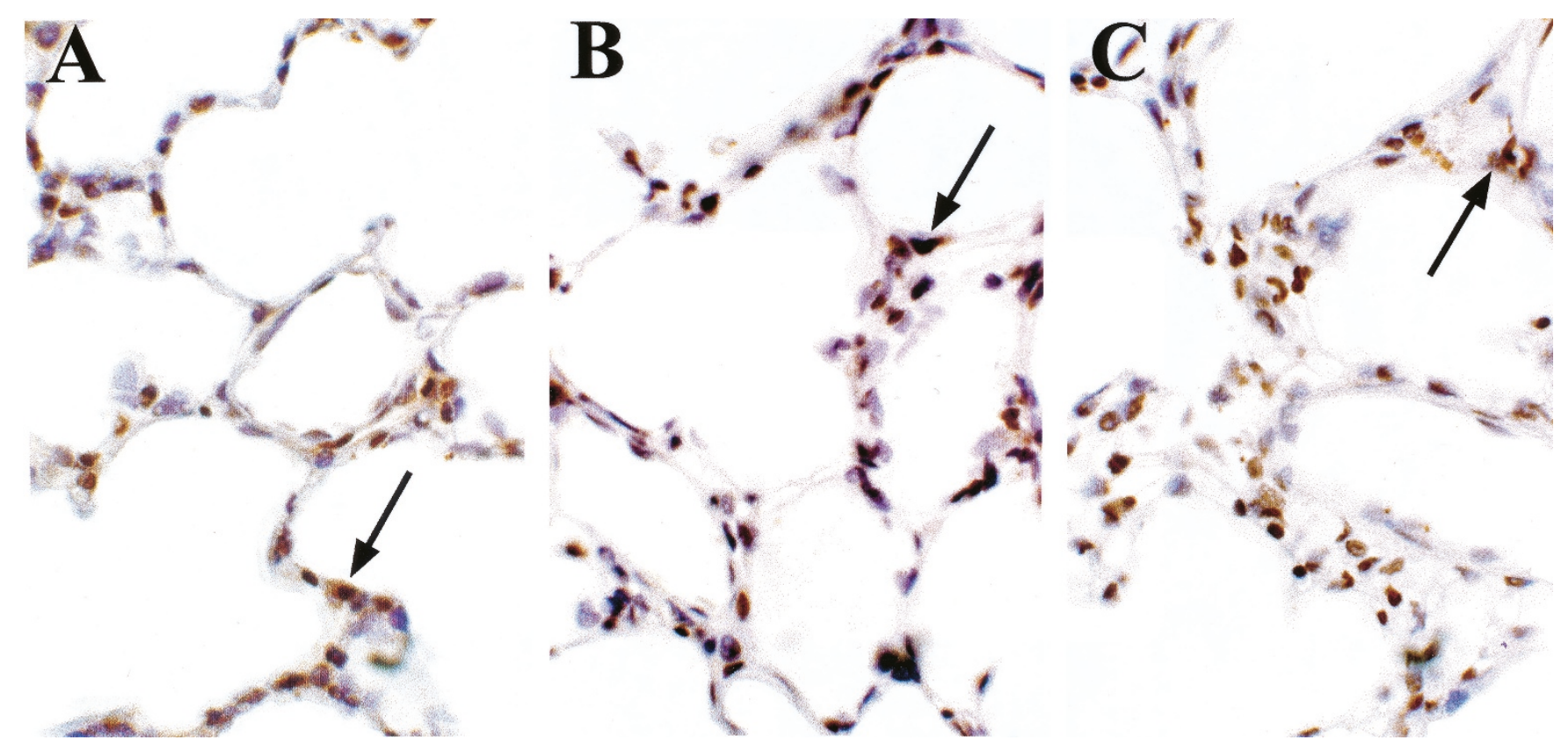

Figure 4. Immunohistochemistry for PDGF-BB protein (brown stain) illustrated at $\mathrm{d} 7$ in the right lungs of control $(A)$, sham-operated $(B)$, and pneumonectomized $(C)$ pups. Examples of immunoreactive cells are identified by arrows. No significant differences in gross immunoreactivity or distribution of immunoreactivity were observed between groups. Original magnification: $\times 400$.

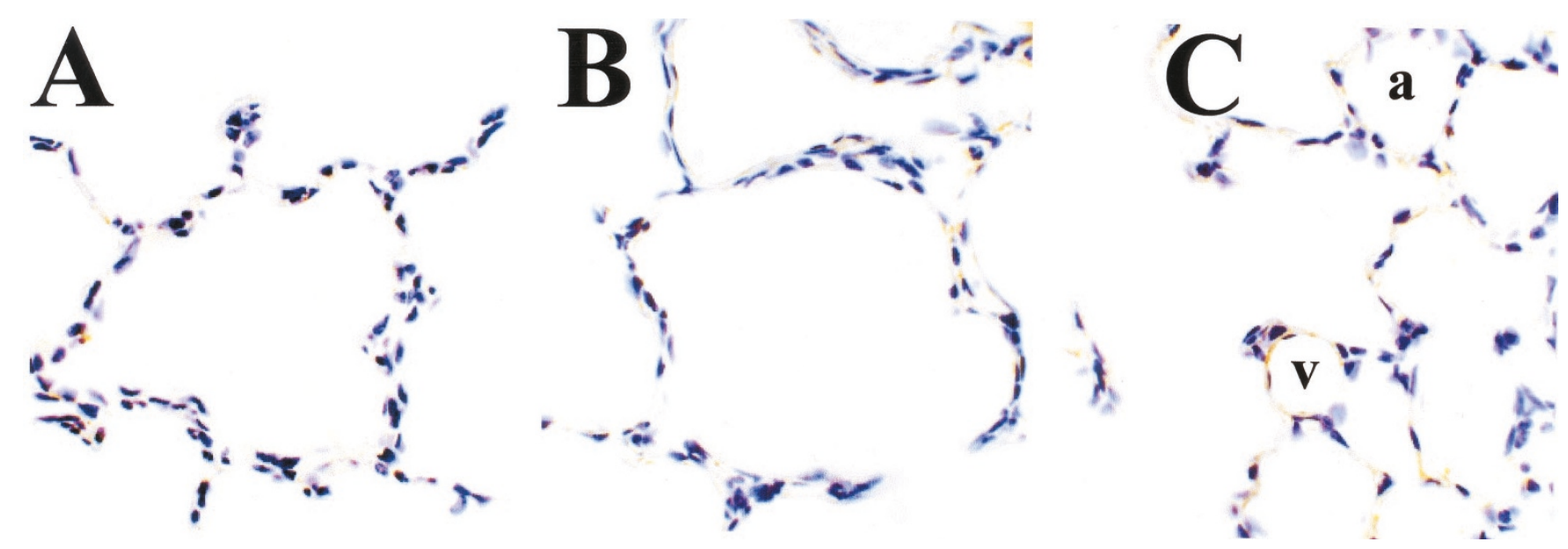

Figure 5. Immunohistochemistry for PDGF-R $\beta$ (brown stain) illustrated at $\mathrm{d} 3$ in the right lungs of control $(A)$, sham-operated $(B)$, and pneumonectomized $(C)$ pups. No significant differences in gross immunoreactivity or distribution of immunoreactivity were observed between groups. Immunoreactivity was most evident on alveolar $(a)$ epithelial cells and the endothelial cells of small vessels $(v)$. Original magnification: $\times 400$. 


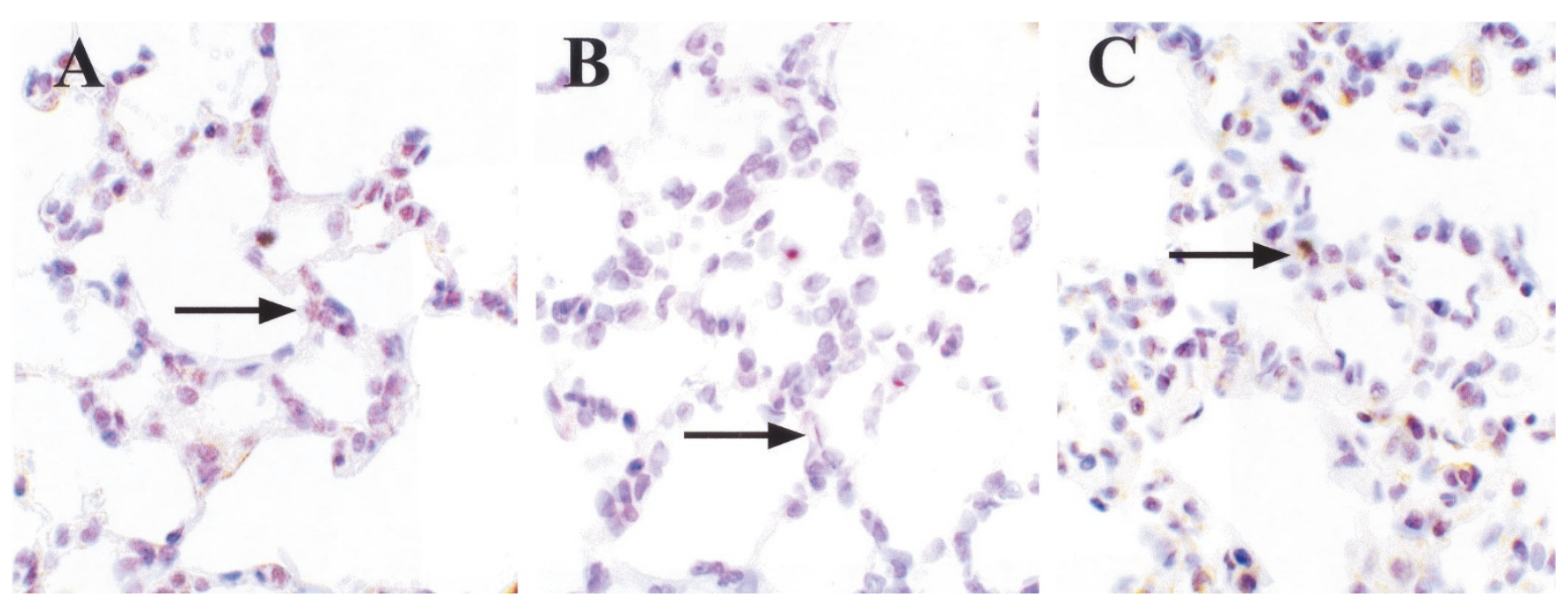

Figure 6. Intraperitoneal injection of PDGF-R $\beta / \mathrm{Fc}$ chimera soluble receptor $(B)$ resulted in a reduction of PDGF-BB immunoreactivity (brown stain) in rat lung compared with the lungs of uninjected rats $(A)$, or rats injected with vehicle alone $(C)$. Examples of immunoreactive cells are identified by arrows. Original magnification: $\times 200$.

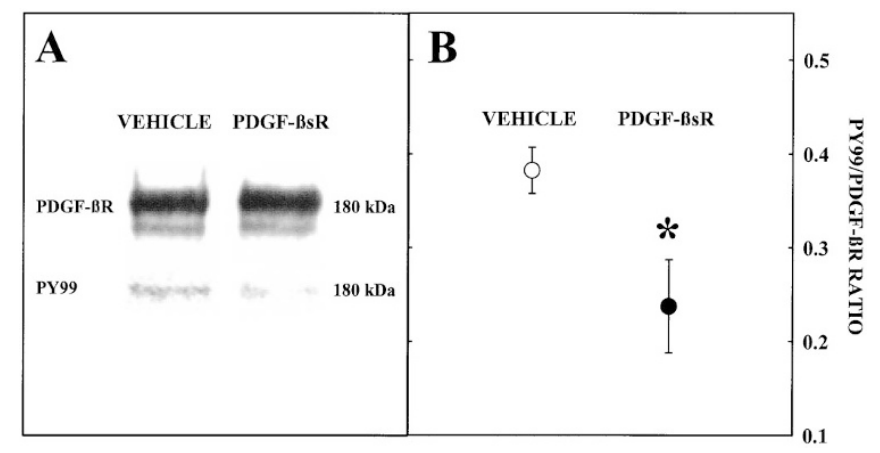

Figure 7. (A) Example of a Western blot for PDGF $\beta$-receptor $(P D G F-\beta R)$ and phosphorylated receptor tyrosine (PY99) in the lungs of pneumonectomized rat pup litter mates that had received either intraperitoneal PDGF-R $\beta / \mathrm{Fc}$ chimera truncated soluble receptor $(P D G F-\beta S R)$ or vehicle alone. $(B)$ Injection of intraperitoneal PDGF-R $\beta / \mathrm{Fc}$ chimera truncated soluble receptor resulted in a significant reduction $\left({ }^{*} p<0.05\right.$ by paired $t$ test) in activation of the natural PDGF $\beta$-receptor, as reflected by densitometric analysis of receptor tyrosine phosphorylation. Values are means \pm SEM for four animals in each group.

soluble receptor $(0.37 \pm 0.6)$. Significant $(p<0.05)$ postpneumonectomy increases in right lung $\left[{ }^{3} \mathrm{H}\right]$ thymidine incorporation into DNA (Fig. 8A), and DNA content (Fig. 8B), were arrested by i.p. injection of the PDGF-R $\beta / \mathrm{Fc}$ chimera, but not the control NGF-R/Fc chimera. Additional animals were injected with the Fc portion of IgG alone, which had no effect on lung DNA synthesis (data not shown). Changes in gross lung weights were less sensitive than measurements of DNA content or of $\left[{ }^{3} \mathrm{H}\right]$ thymidine incorporation into DNA. Right lung weights in control animals were $345 \pm 28 \mathrm{mg}$ increasing to 402 $\pm 19 \mathrm{mg}$ with pneumonectomy. This increase in weight with pneumonectomy was reduced by $\approx 50 \%$ with i.p. injection of the PDGF-R $\beta / \mathrm{Fc}$ chimera $(371 \pm 9 \mathrm{mg}$ ), which did not achieve statistical significance $(p>0.05)$, but not with i.p injection of the NGF-R/Fc chimera (414 $\pm 15 \mathrm{mg})$.

These data could be consistent with an early $(<3 \mathrm{~d})$ increase in PDGF-B and/or PDGF-R $\beta$ mRNA, and protein for PDGF-BB and/or the PDGF-R $\beta$, which would not have been detected at the 3-, 5-, 7-, and 10-d time points previously

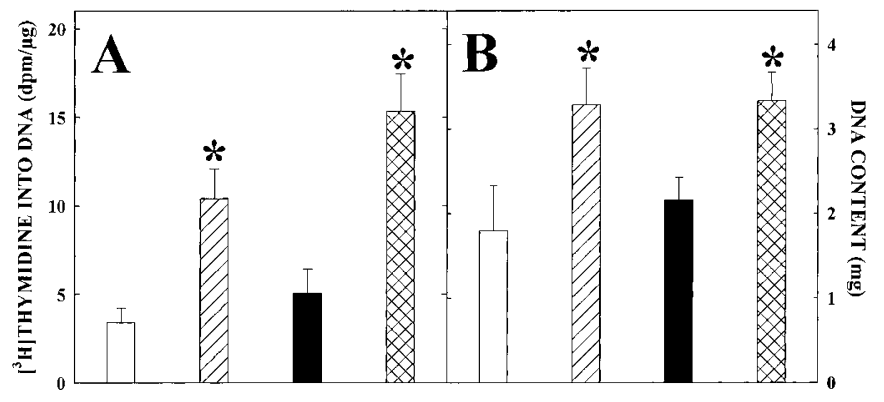

Figure 8. Effect of the PDGF-R $\beta / F c$ chimera truncated soluble receptor on (A) right lung DNA synthesis, as measured by $\left[{ }^{3} \mathrm{H}\right]$ thymidine incorporation into DNA, or $(B)$ DNA content, on d 3 after pneumonectomy. Significant increases $(* p<0.05$ by ANOVA) in both DNA synthesis and DNA content were observed in animals receiving vehicle alone, after pneumonectomy (hatched bar), when compared with unoperated controls (open bar). These increase were attenuated by i.p. injection of the PDGF-R $\beta / F c$ chimera truncated soluble receptor (solid bar). Control animals receiving i.p. NGF-R/Fc had no attenuation of the increases in DNA synthesis or DNA content observed after pneumonectomy (cross-hatched bar). Values are means \pm SEM for six animals in the control and vehicle groups, seven animals in the PDGF-R $\beta / F c$ group, and four animals in the NGF-R/Fc group.

examined. Additional lung tissues from animals was therefore obtained for comparable analysis at $1 \mathrm{~d}$ after pneumonectomy. This time point was selected because a significant increase in DNA synthesis was already evident at $2 \mathrm{~d}$ (Fig. 1). As with the later time points, no differences between groups were evident (data not shown).

\section{DISCUSSION}

The pneumonectomy model selected for use in these studies is a modification of that reported by Holmes and Thurlbeck (9), except that we performed pneumonectomies at an earlier time point, in an effort to achieve the maximum possible signal for compensatory lung growth. This was well tolerated, with no inhibition of body weight gain following surgery. As would be predicted from previously reported studies, compensatory cell division in the residual lung was complete by $10 \mathrm{~d}$ after 
pneumonectomy, as assessed by a measurement of DNA synthesis. We did not conduct a morphometric analysis, but pneumonectomy in young rats has been shown by others to be associated with an increase in alveolar number in the residual lung (9).

In agreement with earlier studies $(5,40)$, both DNA content in the right lung and $\left[{ }^{3} \mathrm{H}\right]$ thymidine incorporation into DNA were significantly increased after pneumonectomy. DNA content in the right lung continuously increased postpneumonectomy. Sham operation may have caused a small early effect on DNA content, although this was not statically significant, consistent with a minor stimulatory effect after collapse of the lung. Increased DNA synthesis was an early event after pneumonectomy, being significantly increased as early as d 2 after surgery, with peak activity at d 5 and a significantly increased rate of DNA synthesis still evident at $d 7$.

We hypothesized that PDGF-BB activation of the PDGF-R $\beta$ would be a mediator of postpneumonectomy compensatory lung growth. Consistent with this hypothesis was an increase in the total PDGF-B mRNA and PDGF-BB content in the residual lung after pneumonectomy. However, no increase was evident when these values were normalized against $\beta$-actin and milligrams of protein, respectively, consistent with their expression being tightly regulated. It was therefore possible that the late increases observed in the residual lung 7 and $10 \mathrm{~d}$ after pneumonectomy were simply a reflection of a constitutive normalization of tissue content, without PDGF-BB or its receptor being actively involved in compensatory lung growth.

That activation of the PDGF-R $\beta$ by PDGF-BB was of importance in the process of compensatory lung growth was revealed by the use of a truncated soluble receptor (PDGF$\mathrm{R} \beta / \mathrm{Fc}$ chimera) approach. We have previously used this approach to demonstrate a critical role for PDGF-BB in normal postnatal lung growth in the newborn rat (34). The soluble receptor bound to PDGF-BB, both reducing its accessibility to antibody and limiting its potential for binding and activation of its native PDGF-R $\beta$ in vivo. This, in turn, attenuated the increase in DNA synthesis and DNA mass normally evident in the residual lung after pneumonectomy. Lack of effect in either NGF-R/Fc chimera- or IgG (Fc)-injected controls suggested a specific effect of the PDGF-R $\beta / \mathrm{Fc}$ chimera on binding of PDGF-BB to the PDGF-R $\beta$. An effect through binding of the PDGF-R $\beta / \mathrm{Fc}$ chimera to other forms of PDGF can be excluded, inasmuch as neither PDGF-AA nor PDGF-AB bind with high affinity to the PDGF-R $\beta$ (41). What our data does not allow us to absolutely exclude is an effect of PDGF-BB on the PDGF $\alpha$-receptor, which can bind all PDGF isoforms. However, this seems unlikely to account for the observed effect, in that binding of PDGF-BB by the PDGF-R $\beta / F c$ chimera would leave binding of PDGF-AA to the PDGF $\alpha$-receptor unopposed and would not prevent PDGF $\alpha$-receptor-mediated signaling.

We have not specifically assessed the cell types responsive to PDGF-BB by increased DNA synthesis in this model. Both alveolar epithelial cells and small vessel endothelial cells expressed the PDGF-R $\beta$, and are likely targets. Microvascular endothelial cells from developing lung increase DNA synthesis in response to PDGF-BB (42). Isolated type II pneumocytes from animals of a similar age also respond to PDGF-BB with an increase in DNA synthesis, unlike type II pneumocytes from completely mature animals, which are unresponsive (43).

In summary, there are apparently tightly regulated increases in residual lung PDGF-B mRNA and PDGF-BB over the first $10 \mathrm{~d}$ following pneumonectomy, which occur in parallel with a compensatory increase in lung DNA content. This could simply reflect a constitutive increase in PDGF-B mRNA and PDGF-BB, unrelated to an increase in DNA synthesis. However, our data do support a critical role for PDGF-BB in early compensatory lung growth in the rat after pneumonectomy. A pharmacological intervention with a truncated PDGF-R $\beta / \mathrm{Fc}$ soluble receptor has allowed us to demonstrate a causal relationship between PDGF-BB and postpneumonectomy compensatory DNA synthesis. This observation also brings into question the assumption that no increase in normalized growth factor mRNA or protein, after pneumonectomy, automatically excludes a role in compensatory growth, as reported for IGF-I (20).

\section{REFERENCES}

1. Laros CD, Westermann CJJ 1987 Dilatation, compensatory growth, or both after pneumonectomy during childhood and adolescence. A thirty-year follow-up study. J Thorac Cardiovasc Surg 93:570-576

2. Arnup ME, Greville HW, Oppenheimer L, Mink SN, Anthonisen NR 1984 Dynamic lung function in dogs with compensatory lung growth. J Appl Physiol 57:1569-1576

3. Brody JS 1975 Time course of and stimuli to compensatory growth of the lung after pneumonectomy. J Clin Invest 56:897-904

4. Buhain WJ, Brody JS 1973 Compensatory growth of the lung following pneumonectomy. J Appl Physiol 35:898-902

5. Cagle PT, Thurlbeck WM 1988 Postpneumonectomy compensatory lung growth. Am Rev Respir Dis 138:1314-1326

6. Das RM, Thurlbeck WM 1979 The events in the contralateral lung following pneumonectomy in the rabbit. Lung 156:165-172

7. Rannels DE, Rannels SR 1988 Compensatory growth of the lung following partial pneumonectomy. Exp Lung Res 14:157-182

8. Burri PH, Sehovic S 1979 The adaptive response of the rat lung after bilobectomy. Am Rev Respir Dis 119:769-777

9. Holmes C, Thurlbeck WM 1979 Normal lung growth and response after pneumonectomy in the rat at various ages. Am Rev Respir Dis 120:1125-1136

10. Rannels DE, White DM, Watkins CA 1979 Rapidity of compensatory lung growth following pneumonectomy in adult rats. J Appl Physiol 46:326-333

11. Watkins CA, Burkhart LR, Rannels DE 1985 Lung growth in response to unilateral pneumonectomy in rapidly growing rats. Am J Physiol 248:E162-E169

12. Kuboi S, Mizuuchi A, Mizuuchi T, Taguchi T, Thurlbeck WM, Kida K 1992 DNA synthesis and related enzymes altered in compensatory lung growth in rats. Scand J Clin Lab Invest 52:707-715

13. Thet LA, Law DJ 1984 Changes in cell number and lung morphology during early postpneumonectomy lung growth. J Appl Physiol 56:975-978

14. Brody JS, Burki R, Kaplan N 1978 Deoxyribonucleic acid synthesis in lung cells during compensatory lung growth after pneumonectomy. Am Rev Respir Dis 117:307-316

15. Gilbert K, Petrovic-Dovat AL, Rannels DE 1997 Hormonal control of compensatory lung growth. In: McDonald JA (ed) Lung Growth and Development. Marcel Dekker, New York, pp 627-660

16. Gilbert KA, Rannels DE 1998 Increased lung inflation induces gene expression after pneumonectomy. Am J Physiol 275:L21-L29

17. Dubaybo BA, Bayasi G, Rubeiz GJ 1995 Changes in tumor necrosis factor in postpneumonectomy lung growth. J Thorac Cardiovasc Surg 110:396-404

18. Thurlbeck WM, D'Ercole AJ, Smith BT 1984 Serum somatomedin C concentrations following pneumonectomy. Am Rev Respir Dis 130:499-500

19. McAnulty RJ, Guerreiro D, Cambrey AD, Laurent GJ 1992 Growth factor activity in the lung during compensatory lung growth after pneumonectomy: evidence of a role for IGF-1. Eur Respir J 5:739-747

20. Price WA, Moats-Staats BM, Sekhon HS, Chrzanowska BL, Thurlbeck WM, Stiles AD 1998 Expression of the insulin-like growth factor system in postpneumonectomy lung growth. Exp Lung Res 24:203-218

21. Nobuhara KK, DiFiore JW, Ibla JC, Siddiqui AM, Ferretti ML, Fauza DO, Schnitzer JJ, Wilson JM 1998 Insulin-like growth factor-1 gene expression in three models of accelerated lung growth. J Pediatr Surg 33:1057-1060

22. Sugahara K, Matsumoto M, Baba T, Nakamura T, Kawamoto T 1998 Elevation of serum hepatocyte growth factor (HGF) level in patients with pneumonectomy during a perioperative period. Intensive Care Med 24:434-437

23. Han RNN, Mawdsley C, Souza P, Tanswell AK, Post M 1992 Platelet-derived growth factors and growth-related genes in rat lung. III. Immunolocalization during fetal development. Pediatr Res 31:323-329 
24. Souza P, Tanswell AK, Post M 1996 Different roles for PDGF $\alpha$ and $\beta$ receptors in embryonic lung development. Am J Respir Cell Mol Biol 15:551-562

25. Han RNN, Buch S, Freeman BA, Post M, Tanswell AK 1992 Platelet-derived growth factor and growth-related genes in rat lung. II. Effect of exposure to $85 \% \mathrm{O}_{2}$. Am J Physiol 262:L140-L146

26. Liu M, Liu J, Buch S, Tanswell AK, Post M 1995 Antisense oligonucleotides for PDGF-B and its receptor inhibit mechanical strain-induced fetal lung cell growth. Am J Physiol 269:L178-L184

27. Strauss WM 1994 Preparation of genomic DNA from mammalian tissue. In: Isabel FM, Brent R, Kingston RE, Moore DD, Seidman JG, Smith JA, Struhl K (eds) Current Protocols in Molecular Biology. Wiley Interscience, New York, pp 2.2.1-2.2.3

28. West DC, Sattar A, Kumar S 1985 A simplified in situ solubilization procedure for the detection of DNA and cell number in tissue cultured mammalian cells. Anal Biochem 147:289-295

29. Chomczynski P, Mackey K, Drews R, Wilfinger W 1997 DNAzol: a reagent for the rapid isolation of genomic DNA. Biotechniques 22:550-553

30. Chomczynski P, Sacchi N 1987 Single-step method of RNA isolation by acid guanidine thiocyanate-phenol-chloroform extraction. Anal Biochem 162:156-159

31. Wang J, Souza P, Kuliszewski M, Tanswell AK, Post M 1994 Expression of surfactant proteins in embryonic rat lung. Am J Respir Cell Mol Biol 10:222-229

32. Bornthorn DT, Sultan P, Collins T 1991 Structure of the murine $c$-sis proto-oncogene (Sis, PDGFB) encoding the $\mathrm{B}$ chain of platelet-derived growth factor. Genomics 10:287-292

33. Nudel U, Zakut R, Shani M, Neuman S, Levy Z, Yaffe D 1983 The nucleotide sequence of the rat cytoplasmic beta-actin gene. Nucleic Acids Res 11:1759-1771

34. Buch S, Han RNN, Cabacungan J, Wang J, Yuan S, Belcastro R, Deimling J, Luo X, Lye SJ, Post M, Tanswell AK 2000 Changes in expression of platelet-derived growth factor and its receptors in the lungs of newborn rats exposed to air or $60 \% \mathrm{O}_{2}$. Pediatr Res 48:423-433

35. Chwalinski S, Potten CS, Evans G 1988 Double labelling with bromodeoxyuridine and $\left[{ }^{3} \mathrm{H}\right]$-thymidine of proliferative cells in small intestinal epithelium in steady state and after irradiation. Cell Tissue Kinet 21:317-329

36. Hsu SM, Raine L, Fanger H 1981 Use of avidin-biotin-peroxidase complex (ABC) in immunoperoxidase techniques: a comparison between $\mathrm{ABC}$ and unlabeled antibody (PAP) procedures. J Histochem Cytochem 29:577-580

37. Bradford MM 1976 A rapid and sensitive method for the quantitation of microgram quantities of protein utilizing the principle of protein-dye binding. Anal Biochem $72: 248-254$

38. Snedecor GW, Cochran WG 1980 Statistical Methods. Iowa State University Press, Ames, IA, pp 215-295

39. Snedecor GW, Cochran WG 1980 Statistical Methods. Iowa State University Press, Ames, IA, pp 83-106

40. Cagle PT, Langston C, Goodman JC, Thurlbeck WM 1990 Autoradiographic assessment of the sequence of cellular proliferation in postpneumonectomy lung growth. Am J Respir Cell Mol Biol 3:153-158

41. Claesson-Welsh L 1994 Platelet-derived growth factor receptor signals. J Biol Chem 269:32023-32026

42. Tanswell AK, Han RNN, Jassal D, Fraher LJ, Post M 1991 The response of small vessel endothelial cells from fetal rat lung to growth factors. J Dev Physiol 15:199209

43. Tanswell AK, Buch S, Liu M, Post M 1999 Factors mediating cell growth in lung injury. In: Bland RD, Coalson J (eds) Chronic Lung Disease of Early Infancy. Marcel Dekker, New York, pp 493-534 